\title{
Factors Identification and Conformance of Quality of Cement and Coarse Aggregate used at Gautama Buddha Airport Upgrading Component, Nepal
}

\author{
Anjay Kumar Mishra ${ }^{1}$, Dinesh Gupta ${ }^{2}$ \& P. S. Aithal ${ }^{3}$ \\ ${ }^{1}$ Associate Professor, Madan Bhandari Memorial Academy Nepal, Urlabari 3, Morang, Nepal \\ OrcidID: 0000-0003-2803-4918; Email: anjaymishra2000@gmail.com \\ ${ }^{2}$ Engineer, Tulsipur Sub-Metropolitan, Dang, Nepal \\ Email: guptadines47@gmail.com \\ ${ }^{3}$ Professor, College of Management \& Commerce, Srinivas University, Mangalore, India \\ OrcidID: 0000-0002-4691-8736; E-mail: psaithal@,gmail.com
}

Area/Section: Engineering.

Type of the Paper: Experimental Research.

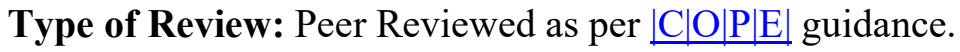

Indexed in: OpenAIRE.

DOI: $\underline{\text { http://doi.org/10.5281/zenodo.4065739 }}$

Google Scholar Citation: IJMTS.

\section{How to Cite this Paper:}

Anjay Kumar Mishra, Dinesh Gupta, \& Aithal, P. S. (2020). Factors Identification and Conformance of Quality of Cement and Coarse Aggregate used at Gautama Buddha Airport Upgrading Component, Nepal. International Journal of Management, Technology, and Social Sciences (IJMTS), 5(2), 187-200. DOI: http://doi.org/10.5281/zenodo.4065739

International Journal of Management, Technology, and Social Sciences (IJMTS)

A Refereed International Journal of Srinivas University, India.

(C) With Author.

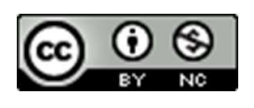

This work is licensed under a Creative Commons Attribution-Non-Commercial 4.0 International License subject to proper citation to the publication source of the work.

Disclaimer: The scholarly papers as reviewed and published by the Srinivas Publications (S.P.), India are the views and opinions of their respective authors and are not the views or opinions of the SP. The SP disclaims of any harm or loss caused due to the published content to any party. 


\title{
Factors Identification and Conformance of Quality of Cement and Coarse Aggregate used at Gautama Buddha Airport Upgrading Component, Nepal
}

\author{
Anjay Kumar Mishra ${ }^{1}$, Dinesh Gupta ${ }^{2}$ \& P. S. Aithal ${ }^{3}$ \\ ${ }^{1}$ Associate Professor, Madan Bhandari Memorial Academy Nepal, Urlabari 3, Morang, Nepal \\ OrcidID: 0000-0003-2803-4918; Email: anjaymishra2000@gmail.com \\ ${ }^{2}$ Engineer, Tulsipur Sub-Metropolitan, Dang, Nepal \\ Email: guptadines47@gmail.com \\ ${ }^{3}$ Professor, College of Management \& Commerce, Srinivas University, Mangalore, India \\ OrcidID: 0000-0002-4691-8736; E-mail: psaithal@gmail.com
}

\begin{abstract}
Quality management system has been challenging in construction of airport project. The objective of study is to assess the factors affecting quality and conformance of Cement and Coarse Aggregate standard used at Construction Site of Gautam Buddha Airport Upgrading Component. This research is based on key informant interview with supervisor and site engineers, questionnaires survey with clients, consultants and contractors who were involved in airport construction projects along with lab test of cement and coarse aggregate of airport construction sites. Statistical tools mean value and relative importance index were used for the ranking of different quality methods. Airport follows specification and standard technical guidelines for the airport construction work. The major factors affecting the quality management in airport construction was Unavailability of competent staff, Low quality drawing and specification and Poor-quality procedure and department for ensuring quality assurance practice Provide training and seminar on quality assurance and Support the setting up of of cube of 3 days, 7 days and 28days is $18.8 \mathrm{~N} / \mathrm{mm}^{2}\left(>16 \mathrm{~N} / \mathrm{mm}^{2}\right), 27.20 \mathrm{~N} / \mathrm{mm}^{2}\left(>22 \mathrm{~N} / \mathrm{mm}^{2}\right)$ and $39.40 \mathrm{~N} / \mathrm{mm}^{2}\left(>33 \mathrm{~N} / \mathrm{mm}^{2}\right)$ respectively. The average initial setting Time and final setting time of cement is $180 \mathrm{~min}(>45 \mathrm{~min})$ and $351 \mathrm{~min}(<600 \mathrm{~min})$ respectively and average soundness of cement is $2.7 \mathrm{~mm}(<10 \mathrm{~mm})$. The test for aggregate, it was found that average Los Angeles Abrasion value of aggregate was $32.8 \%(<40 \%)$, average crushing value of aggregate was $19.88 \%(<25 \%)$, Flakiness index of aggregate found that $19.85 \%(<25 \%)$ and the gradation of aggregate was found that within specification. Quality in airport construction starts from selection of material, inspection, tests employed.
\end{abstract}

Keywords: Factors, Relative Important Index, Compressive Strength, Flakiness index, Los Angels

\section{INTRODUCTION :}

The Quality of a product is a degree of conformation of all the relevant features and characteristics of the products to all aspects of a customer's need, limited by the price and delivery that he or she will accept. Quality is addressing the needs of customer through design requirements under the control of regulatory authority for developing the high utility product in an effective manner in comparison to your competitors [1].

Simply speaking, addressing need of client in design and making specification based of design which is better than competitors within same cost following regulatory authority requirements are to be addressed for saying thing of quality. Gautam Buddha Airport Upgrading Component under construction as second airport of Nepal.

Anjay Kumar Mishra, et al, (2020); www.srinivaspublication.com

PAGE 188 
Airport must be insured a good quality of construction for the safety of air traffic flow and management so quality of construction is very important for a construction project like international airport. So, the quality management practice must be observed closely at airport ensuring effective construction the researcher is interested to assess the factor affecting quality management practices. Its application and quality of material used at site.

The study will be significance of construction stockholder to assess the factor of quality management as a lesson to be learned for future airport construction project. it will be a quality document for practicing engineers to maintained quality management practice in their respective project. It would also attempt to reveal how quality management systems are established in project procurement and what kind of tests are been performed at site for maintaining the quality of work. The findings are expected to be valuable in future projects.

\section{OBJECTIVE:}

Overall, all objective of the study is to assess the factors affecting quality and conformance of Cement and Coarse Aggregate standard used at Construction Site of Gautam Buddha Airport Upgrading Component. The specific objective of the study is to:

(1) To assess the factors affecting quality management.

(2)To analyze the strength of cement and coarse aggregate used in construction site.

\section{LITERATURE REVIEW:}

\subsection{Concept}

Quality and grade should be understood differently. Grade is a category or a rank given to entity having the same functional use but different requirements. A high-grade service may be or low quality if does not meet requirements and conversely, a low-grade service may be of high quality [2].

Quality can be defined as:

$Q=P / E$ Where, $Q=$ Quality, $P=$ Performance and $E=$ Expectations

If $\mathrm{Q}$ is greater than 1, then the project utility is more, the determination of $\mathrm{P}$ and $\mathrm{E}$ will most likely be subjective with the organization assuring performance and the conformance of the expectation.

\subsection{Factor Affecting the Quality Management}

Setting up venture prerequisites at the undertaking origin stage could influence the nature of finished task. As referenced, that, nature of any development venture was meeting the prerequisites of the planner, constructor and administrative organizations just as the owner. The accompanying Figure 1 shows the task prerequisites of the architect, constructor, administrative organizations and the owner, that could be meet by upgrading the undertaking quality as found in key writing. Appropriately, a cautious harmony between the owner's necessities of the undertaking expenses and timetable, wanted working qualities, materials of development, and so forth and the plan Perficient's requirement for satisfactory time and financial plan to meet those prerequisites during the plan cycle was fundamental. Owner s balances their necessities against monetary contemplations and, at times, against possibility of disappointment. The plan proficient was committed to secure general wellbeing and wellbeing with regards to the last finished project. The constructor was liable for the methods, strategies, procedures, successions, and techniques of development, just as security safety measures and projects during the development cycle. The finish of undertaking as per the task necessities could be guaranteed by the nature of its development. Task prerequisites are the key primary elements impacting development venture quality. Be that as it may, it very well may be impacted by numerous elements. As indicated by an investigation by, the executives' duty and authority in development associations could influence development quality. It was on the grounds that, the helpless administration rehearses legitimately and by implication lead to decay of development profitability and at last impact on venture quality. In development terms, cost, plan, and potentially quality objectives are built up for each undertaking. Undertaking administrators are compensated based on meeting these objectives. Further, the quality groups give organizations the organized condition fundamental for effectively actualizing and consistently applying the quality in development. As additional expressed, degree of collaboration of gatherings taking an interest in the plan stage was discovered to be the most significant factor

Anjay Kumar Mishra, et al, (2020); www.srinivaspublication.com 


\section{International Journal of Management, Technology, and Social Sciences (IJMTS), ISSN: 2581-6012, Vol. 5, No. 2, October 2020.}

that influences quality cooperation among gatherings, for example, Structural Engineers, Electrical Engineers, Environmental Engineers, Civil Engineers, Architects, and owner s was basic to arrive at the quality objectives for plan. Further, in the development stage, degree of collaboration of gatherings taking an interest in the development cycle was discovered to be very important [2].

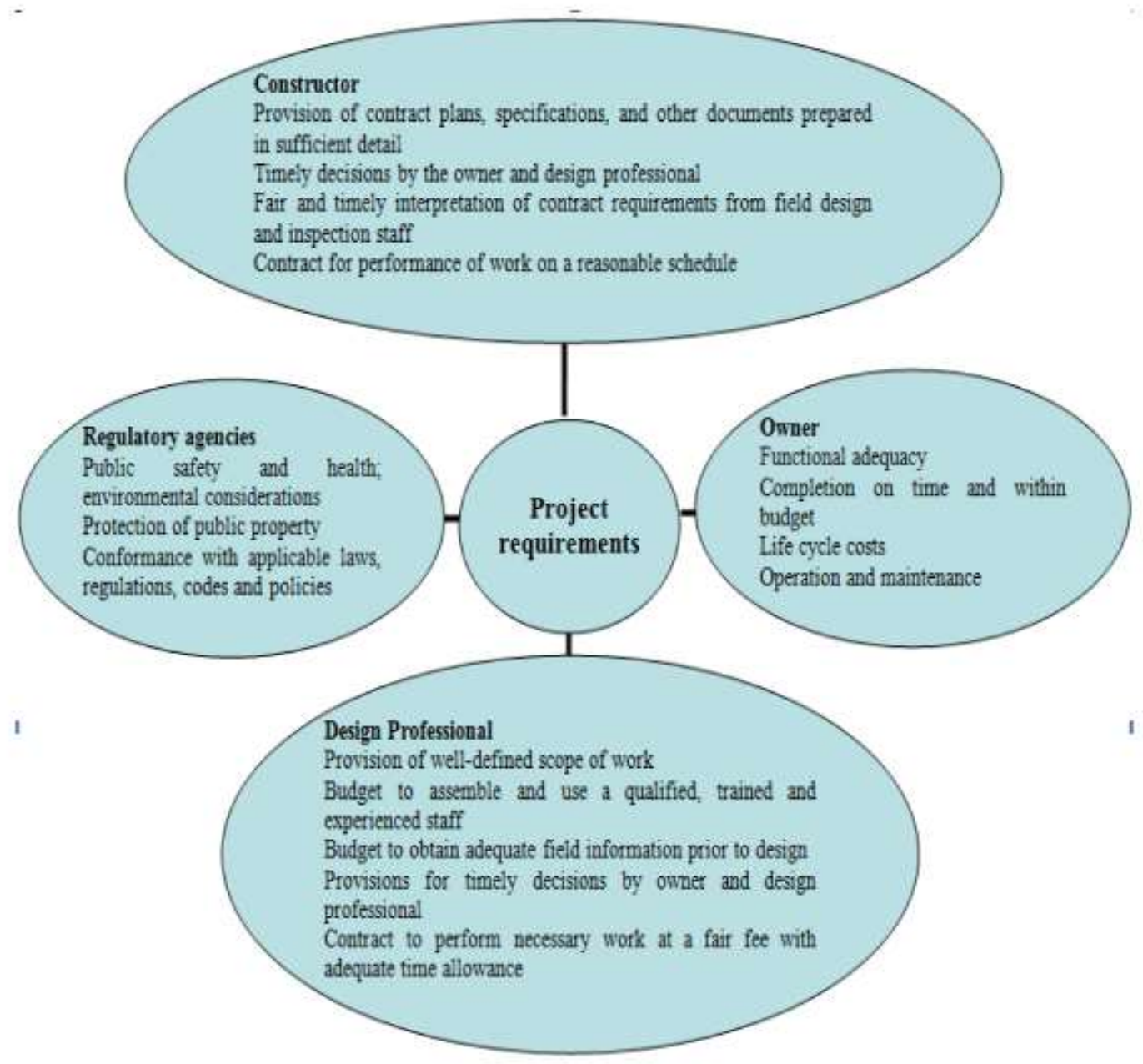

Fig 1: Project Requirements

Building up the undertaking prerequisites for quality starts at venture origin. A cautious harmony between the owner 's necessities of the task expenses and timetable, wanted working attributes, materials of development, and so on and the plan proficient's requirement for sufficient time and financial plan to meet those prerequisites during the plan cycle is basic. Owner $\mathrm{s}$ balance their prerequisites against monetary contemplations and, sometimes, against possibility of disappointment. The plan proficient is committed to secure general wellbeing and wellbeing with regards to the last finished undertaking. The constructor is liable for the methods, strategies, methods, groupings, and methodology of development; just as wellbeing safeguards and projects during the development cycle Project necessities are the key factors that characterize quality during the time spent development. The cycle of development can be separated into three principle stages, to be specific, the arranging and configuration stage, the development stage, and the upkeep and activity stage. 
The constructor was answerable for the methods, strategies, methods, groupings, and methodology of development, just as security safety measures and projects during the development cycle. The finishing of venture as per the task prerequisites could be guaranteed by the nature of its development. Venture prerequisites are the key fundamental variables affecting development venture quality. In any case, it tends to be impacted by numerous variables. As indicated by an investigation by, the executives duty and initiative in development associations could influence development quality. It was on the grounds that, the helpless administration rehearses legitimately and by implication lead to decay of development efficiency and eventually impact on venture quality. In development terms, cost, plan, and potentially quality objectives are set up for each task. Undertaking chiefs are compensated based on meeting these objectives. Further, the quality groups give organizations the organized condition vital for effectively executing and constantly applying the quality in development. As additional expressed, degree of cooperation of gatherings partaking in the plan stage was discovered to be the most significant factor that influences quality collaboration among gatherings, for example, Structural Engineers, Electrical Engineers, Environmental Engineers, Civil Engineers, Architects, and proprietors was fundamental to arrive at the quality objectives for plan. Further, in the development stage, degree of collaboration of gatherings partaking in the development cycle was discovered to be very important [3].

Setting up the venture prerequisites for quality starts at venture commencement. A cautious harmony between the proprietor's prerequisites of the venture expenses and timetable, wanted working attributes, materials of development, and so forth and the plan proficient's requirement for satisfactory time and spending plan to meet those necessities during the plan cycle is fundamental. Proprietors balance their prerequisites against monetary contemplations and, at times, against possibility of disappointment. The plan proficient is committed to ensure general wellbeing and security with regards to the last finished venture. The constructor is liable for the methods, strategies, methods, successions, and techniques of development, just as security safety measures and projects during the development cycle Project necessities are the key factors that characterize quality during the time spent development. The cycle of development can be separated into three primary stages, specifically, the arranging and configuration stage, the development stage, and the upkeep and activity stage.

\section{METHODOLOGY:}

Research Conceptualization: The research is an experimental quantitative and descriptive. The major constructs of the research methodology is given in Table 1.

Table 1. Research Matrix

\begin{tabular}{|l|l|l|l|l|}
\hline SN & Objectives & Data Sources & Methodology & Analysis \\
\hline 1) & $\begin{array}{l}\text { To access the factor's } \\
\text { affecting quality } \\
\text { management of GBAUC }\end{array}$ & $\begin{array}{l}\text { Literature review, Project } \\
\text { manager's and other } \\
\text { employee's experience. }\end{array}$ & $\begin{array}{l}\text { Questionnaire Survey, } \\
\text { KII, field visit }\end{array}$ & $\begin{array}{l}\text { the factor's affecting } \\
\text { quality management } \\
\text { of GBAUC }\end{array}$ \\
\hline 2) & $\begin{array}{l}\text { To analyze the strength of } \\
\text { cement and coarse aggregate } \\
\text { used in GBAUC }\end{array}$ & Lab tests & $\begin{array}{l}\text { Test of material cement, } \\
\text { and coarse aggregate at } \\
\text { lab }\end{array}$ & $\begin{array}{l}\text { quality of material of } \\
\text { cement, and coarse } \\
\text { aggregate }\end{array}$ \\
\hline
\end{tabular}

In this study, Factor of Quality was assessed and strength of Cement and Coarse Aggregate was conformed. Later on, it is analyzed and interpreted the significance of findings to provide conclusions and recommendations.

\section{STUDY AREA :}

Bhairahawa International Airport Construction

Construction of Runway Size: $3,000 \mathrm{~m}$ x $45 \mathrm{~m}$ exclusive of $7.50 \mathrm{~m}$ shoulder at both sides and Construction of Taxiway Size: 1,900m x 30m with RESA (300x90) on different layer (fill type-1, sub-base course, base course, 


\section{International Journal of Management, Technology, and Social Sciences}

(IJMTS), ISSN: 2581-6012, Vol. 5, No. 2, October 2020.

\section{SRINIVAS PUBLICATION}

bituminous base course, asphalt concrete binder course, tack coat). Construction of apron (148x350) on different layer (Fill type-1, sub-base, cement treated base course, PCC). Construction of building: ITB 15,169 Sq.m. (arrival and departure), Sub Station/ Admin/ control tower 2,141 Sq. m and CFR 1,608 Sq.m. Construction of drainage system parrallel to runway, taxiway and diersion of Ghagra Khola along with Airport boundary.Construction of internal and external periphery road,airport access road, CFR access road [4]. As shown in below figure number 2 the Project 3-D Master Plan and response collected based on table number 2 are as follow [5].

Table 2: List of responses received

\begin{tabular}{|c|c|c|c|c|}
\hline \multirow{2}{*}{ S.N. } & \multirow{2}{*}{ Categories } & \multicolumn{3}{|c|}{ No. of responses received } \\
\cline { 3 - 5 } & & Clients & Consultants & Contractors \\
\hline 1 & Engineers, & 6 & 6 & 8 \\
\hline 2 & Supervisors & 3 & 3 & 4 \\
\hline & Sub-Total & $\mathbf{9}$ & $\mathbf{9}$ & $\mathbf{1 2}$ \\
\hline & Total & \multicolumn{3}{|c}{} \\
\hline
\end{tabular}

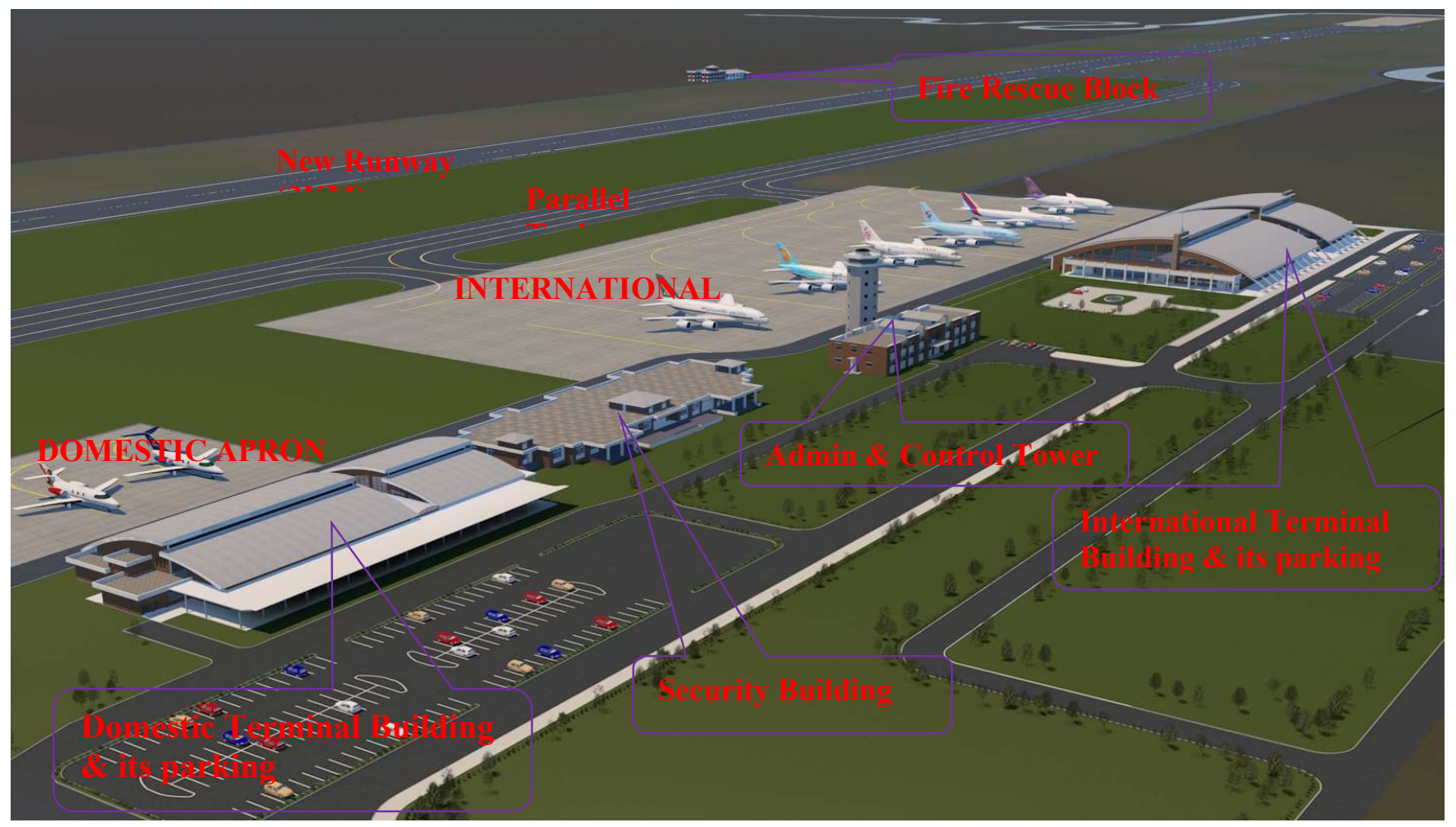

Fig 2: Project 3-D Master Plan 


\section{DATA COLLECTION AND ANALYSIS:}

\section{Data Collection}

The primary data were collected by field visit, interview, questionnaire of the personnel Client, Consultant and contractor (Engineers/Supervisors) involved in the construction of GBAUC.

\section{Schedules Questionnaire}

Factors affecting quality management in Airport construction and responsible parties for ensuring/enforcing quality assurance plan and the benefits and effects of adhering and non-adhering to quality standard in Airport construction were assessed through schedule questionnaire survey.

\section{Key Informant Interview}

Interview with the site project manager, site engineer, lab technician and supervisors were taken were taken from airport construction. It was done by snowball sampling. For the validity and reliability of the questionnaire, key informant interview (KII) were taken with the experts of related sector officers. This interview was taken by meeting the expert of related field.

\section{Lab Tests}

Analysis of quality of cement and coarse aggregate were done at site lab. The Lab tests performed for cement at site are: Compressive Strength Test, setting time test, Soundness test and Normal consistency test following IS Code as adopted from [6]. Similarly, for Coarse aggregate Los Angeles abrasion test, Crushing value test, Gradation test, Water absorption test and Flakiness index test. Documents and reports of airport construction, Quality Assurance plan (QAP) of airport construction, Guidelines provided by airport for construction and several academic articles were reviewed [7].

\section{Data analysis}

The statistical method used for analyzing the data can be briefly explained as:

\section{Mean Value (X)}

The minimum, maximum and the average arithmetic mean $(\mathrm{X})$ values for each issue in the question have been calculated for each group to identify the extreme and average opinion on the issue.

\section{Relative Importance Index (RII)}

Using the following equation, the relative importance index of each sub- factor was calculated as:

Where,

$$
\mathbf{R I I}=\frac{\sum_{\mathrm{i}}^{\mathrm{n}} \mathrm{Wi}}{\mathrm{N} * \mathrm{~A}}
$$

$\mathrm{WI}=$ the rating given to each factor by the respondents ranging from 1-4

$\mathrm{N}=$ Total no. of respondent

$\mathrm{A}=$ Large rating score from respondent

\section{RESULTS AND DISCUSSION:}

\section{Factors Affecting Quality Management in Airport Construction}

The factors affecting quality management in Airport Construction were Unavailability of competent staff, Low quality drawing and specification and Poor-quality procedure and department. As per table 3, Clients and contractors give major factor affecting quality management in Airport Construction was Poor quality procedure and department. The factors affecting according to consultants are Bureaucracy, Low quality drawing and 
International Journal of Management, Technology, and Social Sciences (IJMTS), ISSN: 2581-6012, Vol. 5, No. 2, October 2020.

specification and Material/Equipment specification. The KII gives Unavailability of competent staff, Design complexity, Low quality and poor availability of resources and Supplier impact ware major factors affecting quality management in Airport Construction.

Table 3: Factors affecting quality management in Airport Construction

\begin{tabular}{|c|c|c|c|c|c|c|c|c|}
\hline \multirow[b]{2}{*}{$\begin{array}{r}\text { Factors } \\
\end{array}$} & \multicolumn{2}{|c|}{ Clients } & \multicolumn{2}{|c|}{ Consultants } & \multicolumn{2}{|c|}{ Contractors } & \multicolumn{2}{|c|}{ Overall } \\
\hline & RII & Rank & RII & Rank & RII & Rank & RII & Rank \\
\hline Market share of organization & 0.722 & 45 & 0.722 & 44 & 0.833 & 29 & 0.759 & 45 \\
\hline Liquidity of organization & 0.833 & 28 & 0.778 & 39 & 0.938 & 19 & 0.850 & 28 \\
\hline Cash flow of project & 0.917 & 17 & 0.889 & 22 & 0.958 & 10 & 0.921 & 21 \\
\hline Project design cost & 0.889 & 23 & 0.917 & 12 & 0.979 & 1 & 0.928 & 19 \\
\hline Material and equipment cost & 0.917 & 17 & 0.944 & 5 & 0.979 & 1 & 0.947 & 7 \\
\hline Project labour cost & 0.944 & 7 & 0.917 & 12 & 0.958 & 10 & 0.940 & 12 \\
\hline Project overtime cost & 0.889 & 23 & 0.889 & 22 & 0.938 & 19 & 0.905 & 25 \\
\hline Escalation of material prices & 0.917 & 17 & 0.917 & 12 & 0.979 & 1 & 0.938 & 16 \\
\hline Lack of contractor supervision & 0.889 & 23 & 0.917 & 12 & 0.938 & 19 & 0.914 & 22 \\
\hline $\begin{array}{l}\text { Poor relationship and partnering } \\
\text { among project participants }\end{array}$ & 0.806 & 29 & 0.833 & 28 & 0.792 & 35 & 0.810 & 32 \\
\hline $\begin{array}{l}\text { Reduced Subcontractor } \\
\text { responsibility }\end{array}$ & 0.861 & 27 & 0.861 & 26 & 0.813 & 30 & 0.845 & 29 \\
\hline $\begin{array}{l}\text { Inappropriate method of } \\
\text { contractor }\end{array}$ & 0.944 & 7 & 0.917 & 12 & 0.958 & 10 & 0.940 & 12 \\
\hline $\begin{array}{l}\text { Poor quality procedure and } \\
\text { department }\end{array}$ & 0.972 & 2 & 0.944 & 5 & 0.979 & 1 & 0.965 & 3 \\
\hline Lack of auditing system & 0.944 & 7 & 0.917 & 12 & 0.958 & 10 & 0.940 & 12 \\
\hline Poor Training system & 0.778 & 36 & 0.806 & 33 & 0.792 & 35 & 0.792 & 37 \\
\hline $\begin{array}{l}\text { Low quality continues } \\
\text { improvement }\end{array}$ & 0.944 & 7 & 0.833 & 28 & 0.875 & 28 & 0.884 & 26 \\
\hline Lack of process improvement & 0.778 & 36 & 0.889 & 22 & 0.917 & 24 & 0.861 & 27 \\
\hline $\begin{array}{l}\text { Lack of Management } \\
\text { commitment }\end{array}$ & 0.917 & 17 & 0.917 & 12 & 0.938 & 19 & 0.924 & 20 \\
\hline Lack of quality policy & 0.944 & 7 & 0.833 & 28 & 0.958 & 10 & 0.912 & 23 \\
\hline $\begin{array}{l}\text { Low effective project } \\
\text { management system }\end{array}$ & 0.806 & 29 & 0.861 & 26 & 0.813 & 30 & 0.826 & 30 \\
\hline Bureaucracy & 0.778 & 36 & 1.278 & 1 & 0.771 & 41 & 0.942 & 11 \\
\hline Supplier impact & 0.917 & 17 & 0.500 & 45 & 0.979 & 1 & 0.799 & 36 \\
\hline $\begin{array}{l}\text { Low quality drawing and } \\
\text { specification }\end{array}$ & 0.972 & 2 & 0.972 & 2 & 0.958 & 10 & 0.968 & 2 \\
\hline Design complexity & 0.944 & 7 & 0.917 & 12 & 0.979 & 1 & 0.947 & 7 \\
\hline
\end{tabular}

Anjay Kumar Mishra, et al, (2020); www.srinivaspublication.com 
International Journal of Management, Technology, and Social Sciences (IJMTS), ISSN: 2581-6012, Vol. 5, No. 2, October 2020.

SRINIVAS PUBLICATION

\begin{tabular}{|l|c|c|c|c|c|c|c|c|}
\hline Difficult data collection system & 0.806 & 29 & 0.806 & 33 & 0.813 & 30 & 0.808 & 33 \\
\hline $\begin{array}{l}\text { Poor performance of quality } \\
\text { tools }\end{array}$ & 0.917 & 17 & 0.889 & 22 & 0.917 & 24 & 0.907 & 24 \\
\hline $\begin{array}{l}\text { Difficult application of quality } \\
\text { system }\end{array}$ & 0.944 & 7 & 0.917 & 12 & 0.958 & 10 & 0.940 & 12 \\
\hline Lack of Quality training/meeting & 0.778 & 36 & 0.806 & 33 & 0.792 & 35 & 0.792 & 37 \\
\hline Unavailability of competent staf & 1.000 & 1 & 0.972 & 2 & 0.979 & 1 & 0.984 & 1 \\
\hline Nature uniqueness & 0.778 & 36 & 0.806 & 33 & 0.792 & 35 & 0.792 & 37 \\
\hline Project size and complexity & 0.972 & 2 & 0.944 & 5 & 0.979 & 1 & 0.965 & 3 \\
\hline $\begin{array}{l}\text { Material/Equipment } \\
\text { specification }\end{array}$ & 0.944 & 7 & 0.972 & 2 & 0.958 & 10 & 0.958 & 5 \\
\hline Project Environment & 0.806 & 29 & 0.833 & 28 & 0.813 & 30 & 0.817 & 31 \\
\hline $\begin{array}{l}\text { Low quality and poor availabilit } \\
\text { of resources }\end{array}$ & 0.889 & 23 & 0.944 & 5 & 0.979 & 1 & 0.938 & 16 \\
\hline Lack of motivation & 0.806 & 29 & 0.833 & 28 & 0.771 & 41 & 0.803 & 34 \\
\hline $\begin{array}{l}\text { Incompatible tendering } \\
\text { procedures }\end{array}$ & 0.944 & 7 & 0.944 & 5 & 0.958 & 10 & 0.949 & 6 \\
\hline Low tendency to teamwork & 0.778 & 36 & 0.778 & 39 & 0.792 & 35 & 0.782 & 42 \\
\hline Employee attitudes & 0.944 & 7 & 0.917 & 12 & 0.938 & 19 & 0.933 & 18 \\
\hline $\begin{array}{l}\text { Recruitment and competence } \\
\text { development }\end{array}$ & 0.972 & 2 & 0.944 & 5 & 0.917 & 24 & 0.944 & 9 \\
\hline Belonging to work & 0.778 & 36 & 0.806 & 33 & 0.792 & 35 & 0.792 & 37 \\
\hline Employees motivation & 0.806 & 29 & 0.778 & 39 & 0.813 & 30 & 0.799 & 35 \\
\hline $\begin{array}{l}\text { Application of health and safety } \\
\text { factors in organization }\end{array}$ & 0.972 & 2 & 0.944 & 5 & 0.917 & 24 & 0.944 & 9 \\
\hline Project location is safe to reach & 0.778 & 36 & 0.778 & 39 & 0.750 & 43 & 0.769 & 43 \\
\hline $\begin{array}{l}\text { Reportable accidents rate in } \\
\text { project }\end{array}$ & 0.778 & 36 & 0.778 & 39 & 0.750 & 43 & 0.769 & 43 \\
\hline Assurance rate of project & 0.806 & 29 & 0.806 & 33 & 0.750 & 43 & 0.787 & 41 \\
\hline
\end{tabular}

\section{Responsible for Ensuring Quality Assurance Practice in Airport Construction:}

As shown in table 4. The main responsible for ensuring quality assurance practice form client and consultant is Support the setting up of quality assurance department in construction and also from consultant is Provide training and seminar on quality assurance and Enforce statutory requirement and from contactor is Enforcement of quality standards by government and/or other agency in project delivery and Severe penalty for non-compliance to quality standards by government/professional bodies and overall the main responsible for ensuring quality assurance practice are Provide training and seminar on quality assurance and Support the setting up of quality assurance department in construction firms. While doing KII and site observation it was found that the main responsible for ensuring quality assurance practice in airport construction are Support the setting up of quality assurance department in construction firms, provide training and seminar on quality assurance and Enforce statutory requirement.

Anjay Kumar Mishra, et al, (2020); www.srinivaspublication.com 
International Journal of Management, Technology, and Social Sciences (IJMTS), ISSN: 2581-6012, Vol. 5, No. 2, October 2020.

Table 4: Responsible for ensuring quality assurance practice in Airport Construction

\begin{tabular}{|c|c|c|c|c|c|c|c|c|c|c|c|c|}
\hline \multirow[b]{2}{*}{ Necessary Measures } & \multicolumn{3}{|c|}{ Client (\%) } & \multicolumn{3}{|c|}{ Consultant (\%) } & \multicolumn{3}{|c|}{ Contractor (\%) } & \multicolumn{3}{|c|}{ Overall (\%) } \\
\hline & 部 & $\stackrel{0}{Z}$ & 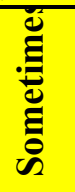 & त्र & o & & 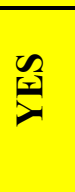 & $\stackrel{0}{Z}$ & 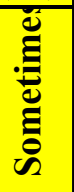 & $\underset{c}{2}$ & $\stackrel{0}{Z}$ & 苛 \\
\hline $\begin{array}{c}\text { Provide training and } \\
\text { seminar on quality } \\
\text { assurance }\end{array}$ & 89 & 0 & 11 & 100 & 0 & 0 & 92 & 0 & 8 & 94 & 0 & 6 \\
\hline $\begin{array}{l}\text { Support the setting up of } \\
\text { quality assurance } \\
\text { department in } \\
\text { construction firms }\end{array}$ & 100 & 0 & 0 & 100 & 0 & 0 & 83 & 0 & 17 & 94 & 0 & 6 \\
\hline $\begin{array}{l}\text { Enforcement of quality } \\
\text { standards by governmen } \\
\text { and/or other agency in } \\
\text { project delivery }\end{array}$ & 89 & 0 & 11 & 89 & 0 & 11 & 92 & 0 & 8 & 90 & 0 & 10 \\
\hline $\begin{array}{c}\text { Severe penalty for non } \\
\text { compliance to quality } \\
\text { standards by } \\
\text { government/professional } \\
\text { bodies }\end{array}$ & 78 & 0 & 22 & 89 & 0 & 11 & 92 & 0 & 8 & 86 & 0 & 14 \\
\hline $\begin{array}{c}\text { Enforce statutory } \\
\text { requirement }\end{array}$ & 89 & 0 & 11 & 100 & 0 & 0 & 83 & 0 & 17 & 91 & 0 & 9 \\
\hline
\end{tabular}

Table 5: Benefits to be derived from application of Quality standard

\begin{tabular}{|c|c|c|c|c|c|c|r|r|}
\hline \multirow{2}{*}{ Benefits } & \multicolumn{2}{|c|}{ Clients } & \multicolumn{2}{c|}{ Consultants } & \multicolumn{2}{c|}{ Contractors } & \multicolumn{3}{c|}{ Overall } \\
\cline { 2 - 9 } & RII & Rank & RII & Rank & RII & Rank & RII & Rank \\
\hline Production of better designs & 0.972 & 2 & 0.944 & 2 & 0.854 & 8 & 0.924 & 5 \\
\hline More effective planning & 0.944 & 5 & 0.917 & 4 & 0.917 & 4 & 0.926 & 4 \\
\hline Improved quality of deliverables & 1.000 & 1 & 0.972 & 1 & 0.938 & 2 & 0.970 & 1 \\
\hline $\begin{array}{c}\text { Enhanced reputation for good desig } \\
\text { and construction for contractors }\end{array}$ & 0.917 & 8 & 0.861 & 6 & 0.958 & 1 & 0.912 & 6 \\
\hline Improved site management & 0.944 & 5 & 0.833 & 8 & 0.833 & 9 & 0.870 & 8 \\
\hline Increased project performance & 0.972 & 2 & 0.917 & 4 & 0.917 & 4 & 0.935 & 2 \\
\hline $\begin{array}{c}\text { Efficient management of } \\
\text { construction problems }\end{array}$ & 0.833 & 9 & 0.861 & 6 & 0.813 & 10 & 0.836 & 10 \\
\hline $\begin{array}{c}\text { Fewer delays of projects and } \\
\text { disruptions }\end{array}$ & 0.972 & 2 & 0.806 & 10 & 0.938 & 2 & 0.905 & 7 \\
\hline $\begin{array}{c}\text { Lower cost of remedial and repeat } \\
\text { works }\end{array}$ & 0.944 & 5 & 0.944 & 2 & 0.896 & 6 & 0.928 & 3 \\
\hline
\end{tabular}

Anjay Kumar Mishra, et al, (2020); www.srinivaspublication.com 
International Journal of Management, Technology, and Social Sciences (IJMTS), ISSN: 2581-6012, Vol. 5, No. 2, October 2020.

\begin{tabular}{|c|c|c|c|c|c|c|c|c|}
\hline $\begin{array}{c}\text { provision of feedback for use in } \\
\text { future projects }\end{array}$ & 0.833 & 9 & 0.833 & 8 & 0.875 & 7 & 0.847 & 9 \\
\hline
\end{tabular}

\section{Benefits of Quality standard in Airport Construction}

In Table 5, Clients and consultant ranked Method "Improved quality of deliverables" as a main priority for benefits to be derived from application of quality standard in airport construction whereas contractor ranked "Enhanced reputation for good design and construction for contractors" as $1^{\text {st }}$ priority. But overall Improved quality of deliverables as $1^{\text {st }}$ rank and Increased project performance as $2^{\text {nd }}$ rank. During site observation and KII it was found that the Lower cost of remedial and repeat works, improved quality of deliverables and increased project performance are major benefits to be derived from application of quality standard in airport construction.

\section{Effects of not Adhering to Quality standards in Airport Construction :}

Questionnaire survey was done with clients, consultants and contractors and find out the effects of not adhering to quality standards in airport construction are Cost overrun on projects, Structural failures leading to death and Poor infrastructural constructed. As per Table 6, Clients give major effects of not adhering to quality standards in airport construction are Cost overrun on projects, Poor infrastructural constructed and affects the nation's development growth. The effects of not adhering to quality standards in airport construction according to consultants are Structural failures leading to death, affects the nation's development and the contractors give major effect of not adhering to quality standards in airport construction is Structural failures leading to death. The KII gives Cost overrun on projects; Poor infrastructural constructed are major effects of not adhering to quality standards in airport construction.

Table 6 : Effects of not adhering to Quality standards

\begin{tabular}{|c|r|r|r|r|r|r|r|r|}
\hline \multirow{2}{*}{ Effect } & \multicolumn{2}{|c|}{ Clients } & \multicolumn{2}{c|}{ Consultants } & \multicolumn{2}{c|}{ Contractors } & \multicolumn{2}{c|}{ Overall } \\
\cline { 2 - 9 } & RII & Rank & RII & Rank & RII & Rank & RII & Rank \\
\hline Cost overrun on projects & 0.972 & 1 & 0.944 & 3 & 0.938 & 2 & 0.951 & 1 \\
\hline Untimely Project Finished & 0.944 & 4 & 0.917 & 5 & 0.792 & 6 & 0.884 & 6 \\
\hline Structural failures leading to death & 0.917 & 6 & 0.972 & 1 & 0.958 & 1 & 0.949 & 2 \\
\hline Poor infrastructural constructed & 0.972 & 1 & 0.944 & 3 & 0.917 & 3 & 0.944 & 3 \\
\hline Damage to reputation & 0.944 & 4 & 0.917 & 5 & 0.896 & 4 & 0.919 & 5 \\
\hline $\begin{array}{c}\text { Affects the nation's development } \\
\text { growth }\end{array}$ & 0.972 & 1 & 0.972 & 1 & 0.833 & 5 & 0.926 & 4 \\
\hline
\end{tabular}

\section{Compressive strength of cement}

During cube test at site, the result was found satisfactory .It was found that average Compressive strength of cube of 3 days strength was found $18.8 \mathrm{~N} / \mathrm{mm}^{2}, 7$ days strength was found $27.20 \mathrm{~N} / \mathrm{mm}^{2}$ and 28 days strength was found $39.40 \mathrm{~N} / \mathrm{mm}^{2}$. The compressive strength acceptance criteria of Compressive strength of cube of 3 days strength is $16 \mathrm{~N} / \mathrm{mm}^{2}, 7$ days strength is $22 \mathrm{~N} / \mathrm{mm}^{2}$ and 28 days strength is $33 \mathrm{~N} / \mathrm{mm}^{2}$ [7].

\section{Soundness of cement.}

During Soundness test of cement at site, the result was found satisfactory. It was found that average soundness of five reading of cement is $2.7 \mathrm{~mm}$. The soundness of cement acceptance criteria of airport specification and standard guidelines are $<10 \mathrm{~mm}[6]$.

\section{Setting Time of cement.}

During setting Time test of cement at site, the result was found satisfactory. It was found that average initial setting Time and final setting time of cement is $180 \mathrm{~min}$. and $351 \mathrm{~min}$. respectively and from KII the initial and final setting time of cement was found that within airport specification and standard guideline that is initial setting 
International Journal of Management, Technology, and Social Sciences

time is $>45 \mathrm{~min}$ and final setting time is $<600 \mathrm{~min}$.

Table 7 : Gradation of Crushed Aggregate test

\begin{tabular}{|c|c|c|c|c|c|c|}
\hline $\begin{array}{l}\text { Type of } \\
\text { Material }\end{array}$ & \multicolumn{2}{|c|}{$\begin{array}{l}: 20 \mathrm{~mm} \\
\text { Crushed } \\
\text { Aggregate } \\
\text { (TinauKhola) }\end{array}$} & & & & \\
\hline $\begin{array}{l}\text { Sample } \\
\text { Location }\end{array}$ & \multicolumn{2}{|c|}{$\begin{array}{l}\text { : Chaitanya } \\
\text { Ready Mix } \\
\text { Concrete Plant }\end{array}$} & & & & \\
\hline Total Wt, gm & \multicolumn{2}{|c|}{10000} & & & & \\
\hline \multicolumn{7}{|c|}{ A. SIEVING DATA } \\
\hline \multirow{2}{*}{$\begin{array}{l}\text { Sieve Size } \\
\text { (mm) }\end{array}$} & \multirow{2}{*}{$\begin{array}{c}\text { Weigh } \\
\text { Retain } \\
\text { d }\end{array}$} & \multirow{2}{*}{$\begin{array}{l}\text { Cmmulat } \\
\text { ve Weigh } \\
\text { Retained }\end{array}$} & \multirow{2}{*}{$\begin{array}{c}\text { Cummula } \\
\text { ve } \\
\text { Retained } \\
(\%)\end{array}$} & \multirow{2}{*}{$\begin{array}{c}\% \\
\text { Passir } \\
\mathrm{g}\end{array}$} & \multicolumn{2}{|c|}{$\begin{array}{l}\text { Specification } \\
\text { Limit IS } 383 \\
\end{array}$} \\
\hline & & & & & $\begin{array}{c}\text { Minimi } \\
\mathrm{m}\end{array}$ & $\begin{array}{c}\text { Maximı } \\
\mathrm{m}\end{array}$ \\
\hline 40.0 & 0 & 0 & 0.00 & 100.0 & 100 & 100 \\
\hline 20.0 & 1229 & 1229 & 12.29 & 87.71 & 85 & 100 \\
\hline 10.0 & 7630 & 8859 & 88.59 & 11.41 & 0 & 20 \\
\hline 4.75 & 877 & 9736 & 97.36 & 2.64 & 0 & 5 \\
\hline pan & 264 & 10000 & 100.00 & $\mathbf{0 . 0 0}$ & & \\
\hline$\frac{\text { B. GRAIN }}{\text { SIZEDISTRI }}$ & & & & & & \\
\hline
\end{tabular}

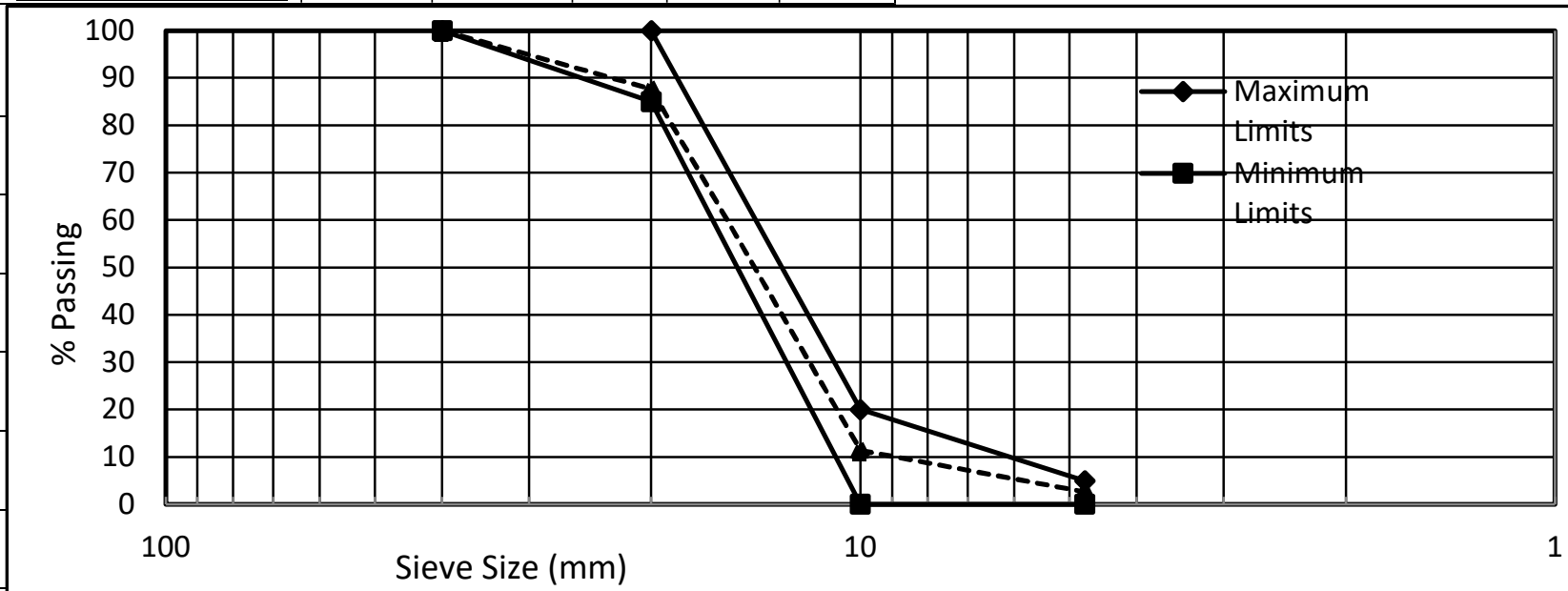

Test of Coarse Aggregate.

Los Angeles Abrasion test of Aggregate.

During Los Angeles Abrasion test of aggregate at site, the result was found satisfactory. It was found that average Los Angeles Abrasion value of aggregate was 32.8\% and from KII the Los Angeles Abrasion value of aggregate was found that within airport specification and standard guideline that is $<40 \%$ [8].

\section{Aggregate crushing value test.}

During Aggregate crushing value test at site. the result was found satisfactory. It was found that average crushing value of aggregate was $19.88 \%$ and from KII the crushing value of aggregate was found that within airport specification and standard guideline that is $<25 \%$ [9].

Anjay Kumar Mishra, et al, (2020); www.srinivaspublication.com 
International Journal of Management, Technology, and Social Sciences (IJMTS), ISSN: 2581-6012, Vol. 5, No. 2, October 2020.

\section{Gradation of Crushed Aggregate test}

During Gradation of Crushed Aggregate at site, the result was found satisfactory. It was found that Gradation of Crushed Aggregate was within specification and standard guideline as shown in table 7.

\section{Flakiness index Test of Aggregate}

During Flakiness index test of aggregate site. the result was found satisfactory. It was found that $19.85 \%$. Flakiness index test of aggregate was within specification and standard guideline is $<25 \%$ as shown in table number 8 [9].

Table 8 : Flakiness index Test of Aggregate

\begin{tabular}{|c|c|c|c|c|}
\hline \multicolumn{2}{|c|}{ Size of aggregates } & \multirow[b]{2}{*}{$\begin{array}{l}\text { Weight of the fraction } \\
\text { consisting of at least } 200 \\
\text { pieces(gm),W }\end{array}$} & \multirow[b]{2}{*}{$\begin{array}{l}\text { Weight of aggregate } \\
\text { in each fraction } \\
\text { passing thickness } \\
\text { gauge }(\mathrm{gm}), \mathrm{X}\end{array}$} & \multirow{2}{*}{$\begin{array}{l}\text { Weight of } \\
\text { aggregate in } \\
\text { each fraction } \\
\text { retained on } \\
\text { thickness gauge } \\
\text { (gm) }\end{array}$} \\
\hline $\begin{array}{c}\text { Passing } \\
\text { through } \\
\text { IS sieve }(\mathbf{m m})\end{array}$ & $\begin{array}{c}\text { Retained on } \\
\text { IS sieve (mm) }\end{array}$ & & & \\
\hline 40.00 & 31.50 & 0.0 & 0.0 & 0.0 \\
\hline 31.50 & 25.00 & 0.0 & 0.0 & 0.0 \\
\hline 25.00 & 20.00 & 1660.0 & 282.0 & 1378.0 \\
\hline 20.00 & 16.00 & 1930.0 & 355.0 & 1575.0 \\
\hline 16.00 & 12.50 & 1988.0 & 342.0 & 1646.0 \\
\hline 12.50 & 10.00 & 1033.0 & 333.0 & 700.0 \\
\hline \multicolumn{2}{|c|}{ Total Wt., gm } & 6611.0 & 1312.0 & 5299.0 \\
\hline \multicolumn{3}{|c|}{ Flakiness Index (\%) } & $(\mathrm{X} / \mathrm{W}) * 100=$ & 19.85 \\
\hline & & Specification Limit & & $<25 \%$ \\
\hline
\end{tabular}

\section{CONCLUSIONS :}

The unavailability of competent staff, low quality drawing and specification and Poor-quality procedure and department were major factors affecting the quality management at Construction of airport. The Provide training and seminar on quality assurance and Support the setting up of quality assurance department in construction firms are major factor were found to be responsible for ensuring quality assurance practice. The Improved quality of deliverables, Increased project performance and lower cost of remedial and repeat works were major benefits to be derived from application of quality standard. The Cost overrun on projects, structural failures leading to death and Poor infrastructural constructed were major effects of not adhering to quality standards in airport construction. During the test of cement and coarse aggregate at site, the result was found satisfactory. It was found that average Compressive strength of cube of 3 days, 7 days and 28 days is $18.8 \mathrm{~N} / \mathrm{mm}^{2}\left(>16 \mathrm{~N} / \mathrm{mm}^{2}\right)$, $27.20 \mathrm{~N} / \mathrm{mm}^{2}\left(>22 \mathrm{~N} / \mathrm{mm}^{2}\right)$ and $39.40 \mathrm{~N} / \mathrm{mm}^{2}\left(>33 \mathrm{~N} / \mathrm{mm}^{2}\right)$ respectively. The average initial setting Time and final setting time of cement is $180 \mathrm{~min}(>45 \mathrm{~min})$ and $351 \mathrm{~min}(<600 \mathrm{~min})$ respectively and average soundness of cement is $2.7 \mathrm{~mm}(<10 \mathrm{~mm})$. The test for aggregate it was found that average Los Angeles Abrasion value of aggregate was $32.8 \%(<40 \%)$, average crushing value of aggregate was $19.88 \%(<25 \%)$, Flakiness index of aggregate found that $19.85 \%(<25 \%)$ and the gradation of aggregate was found that within specification.

\section{RECOMMENDATIONS:}

For ensuring optimum quality management in airport projects, timely ISO audits and inspection must be done regular basis. ICAO supervision should be emphasized for taking care of safety indicator and construction quality during operation of airport. Hence, Quality management in airport construction process can be made effective through the joint effort of all the stakeholders' clients, consultants and contractors involved with comprising all attitudes and responsibilities. Meeting, group discussion, reviews and idea sharing as well as effective control

Anjay Kumar Mishra, et al, (2020); www.srinivaspublication.com 
International Journal of Management, Technology, and Social Sciences (IJMTS), ISSN: 2581-6012, Vol. 5, No. 2, October 2020.

measures and supervision can help for better bonding and understanding of all the stakeholders.

\section{ACKNOWLEDGEMENTS :}

Deepest thanks to all the helping hands without which this work would not have been completed. This research is dedicated to all the people affected from COVID19 and hope the world is going to come over this problem. Great Salutation to medical professionals and security people.

\section{REFERENCES :}

[1] Mishra, A.K. (2019). Assessment of project performance in terms of time cost and quality. (Doctoral dissertation, Ph.D. Thesis, Institute of Business Management, Chhatrapati Shahu Ji Maharaj University Kanpur, India).

[2] Mishra, A. K. (2018). Practices for Quality Management System Adopted in the Bridge Construction Projects of Kathmandu. Nepal. J Adv Res Qual Control Mgmt, 3(1\&2), 42-52.

[3] Senaratne, S. (2015). Importance of Quality for Construction Project Success, Conference on Structural Engineering and Construction Management 2015,University of Moratuwa, Colombo,Srilanka, $11^{\text {th }}-13^{\text {th }}$ December 2015.

[4] Shakya, S, \&Mishra, A. K. (2019). Risk assessment in construction of Gautam Buddha international airport. Journal of Advanced Research in Construction and Urban Architecture, 4(1), 17-34.

[5] Sujata Shakya, Sameer Ratna Bajracharya, \& Anjay Kumar Mishra (2020). Strategy Assessment in Risk Management Practices in Construction of Gautam Buddha International Airport. NOLEGEIN: Journal of Business Risk Management, 3(1), 42-56.

[6] Mishra A. K., Chaudhary U. (2018). Assessment of Cement Handling Behaviour for Selected Construction Sites of Bhatbhateni Supermarket. J. Adv Res Const Urban Arch, 3(3), 1-11.

[7] Mishra, A.K., \&Jha, A. (2019). Quality Assessment of Sarbottam Cement of Nepal. International Journal of Operations Management and Services, 9(1), 1-22.

[8] Yasamis, F. Arditi, D. and Mohammadi, J. (2002). Assessing contractor quality performance. Construction Management and Economics, 20(5), 211-223.

[9] Au, J. C., \& Winnie, W. M. (1999). Quality management for an infrastructure construction project in Hong Kong. Logistics Information Management, 12(4), 309-314.

$* * * * * * *$

Anjay Kumar Mishra, et al, (2020); www.srinivaspublication.com 